\title{
Elastic Moduli of Butt-end Logs and the Variable Knots Distribution in Scots Pine from Western Poland
}

\author{
Radosław Mirski, ${ }^{a}$ Marek Wieruszewski, ${ }^{\mathrm{a}}{ }^{*}$ Adrian Trociński, ${ }^{\mathrm{a}}$ Jakub Kawalerczyk, ${ }^{\mathrm{a}}$ and \\ Karol Łabęda b
}

In studies on Polish pine wood, the parameters determining its usefulness for processing are highly variable. In contrast, international studies on the optimum utilization of coniferous sawn wood describes its visual features as those indicating the distribution of defects and their impact on the selected mechanical and physical properties of sawn wood. Knottiness is one of the qualitative properties of sawn wood that is essential for wood grading. The objective of this study was to determine a correlation between variable knots and their soundness on the one hand and their selected strength parameters on the other. One of the basic issues of this work includes structural timber optimization. For Polish sawn wood, these indicators are still relatively new. The study material involved edged butt-end log lumber from a 120-year-old forest stand. The results confirmed a correlation between knots frequency and modulus of elasticity. The correlation was strong, indicating that sound knots play a major role in the process of the strength assessments. The study did not demonstrate a significant share of rotten knots and their effect on strength.

Keywords: Sawn pine wood; Knots; Optimization; Pre-fabrication

Contact information: a: Department of Wood-based Materials, Faculty of Wood Technology, University of Life Sciences, Poznan, Poland; b: Department of Furniture Design, Faculty of Wood Technology,

University of Life Sciences, Poznan, Poland; *Corresponding author: marek.wieruszewski@up.poznan.pl

\section{INTRODUCTION}

The usefulness of sawn wood strongly depends on the method of log sawing. Sawn wood has different qualitative properties that define its efficiency in prefabrication, depending on whether the material comes from a cross-sectional slice or a long log. The correct management of timber-sawing processes determines which timber-sawing patterns ought to be used for raw materials of various sizes and quality. Proposing appropriate optimization models is the basis of management of sawn wood and factory lumber, and it helps solve the problem of production planning. The currently used optimization systems (such as MiCROTEC, LuxScan, WoodTech, LMI, and WoodInspektor) are based on fault identification and their acceptability for the various sizes and grades of prefabricated products. Only some of the models, mainly those focused on the maximization of the yield of principal product and minimization of byproducts, will provide the desired output (Almecija et al. 2013; Rummukainen et al. 2018; Belley et al. 2019).

The assessment of sawn wood with a view to providing optimum processing into prefabricated products is usually based on visual assessment, supported by nondestructive strength testing. Modulus of elasticity testing is one of the strength characteristics. In classification systems, the decisive role is played by identified 
anatomic defects, such as knots, slope of grain, catface, resinosis, etc. In addition, secondary processing faults, including shakes, discoloration, rot, and crookedness, also play a critical role. Among the above defects, knots are usually decisive in the optimization of timber-sawing to obtain prefabricated defect-free products. In studies on coniferous wood, knots make up as much as $75 \%$ of the defects affecting the sawn wood grading (Duchateau et al. 2013). Knottiness also affects the strength of wood, as measured by the modulus of elasticity, which is correlated with it. Modulus of elasticity (MOE) is the basis of comparative assessment of the technological value of wood originating from Polish forests (Dzbeński 1995; Krzosek 2002, 2009; EN-384 2016; Roszyk 2016; Chmielowski et al. 2018; Lukacevic et al. 2019). The knots disturb the structural uniformity of wood by increasing its hardness and density; they also change the wood fiber orientation (Baltrušaitis 2000; Burawska et al. 2013, 2014). The knotty wood exhibits worse tensile strength, compressive strength, and static bending stiffness in comparison with knotless wood. The log strength depends on the size, soundness, and distribution of knots in the test sample.

Advanced optimization systems are based on the quadrilateral scanning of the sawn wood surface. The use of numerical programs enables the processing of the image of defects and the creation of a signal that optimizes sawn wood grading for commercial use. An assessment of the image of defects for the various sawn wood surfaces enables identification of the incidence of undesirable properties. In that process, the image of the sawn wood sample is divided into several zones and verified for the lengthwise and crosswise incidences and distributions of the defects according to a predetermined division algorithm. The division formula depends on what functions of the preset parameters, determining their acceptable and non-acceptable scopes, were allocated to the sawn wood surface zones. The formula depends strictly on the wood grade, because various wood species are subject to different grading. Therefore, the purpose of optimization for the various wood grades is to find a solution providing information on the presence of defects in the sawn wood vs. zone size. The evaluation process is decided by the creation of a feedback signal, which optimizes the process of sawn wood grading for various commercial uses (Brännströma et al. 2008; Flodin et al. 2008).

Division into zones, or the automatic detection of significant nodes, enables the calculation of a knot area as the cross-sectional area of the knot per total surface area of the sawn wood lengthwise and crosswise (Johansson et al. 2013; Burawska et al. 2014; Dahlen et al. 2018; Lukacevic et al. 2019). Moreover, the algorithms used to-date are capable of correctly fitting the nodes on different sawn wood surfaces with focus on the knots. Among other things, they help predict bending strength with reference to the knot share. The fitting $\mathrm{R}^{2}$ of the model (of the algorithms in question) for Douglas fir (Pseudotsuga Carriere) and for Norway spruce (Picea abies (L.) H. Karst) is estimated to range from 0.59 to 0.72 , and from 0.42 to 0.5 , respectively. Studies have shown that determination of the knot area combined with dynamic modulus of elasticity (MOEdyn) may provide an even more precise assessment of modulus of rupture (MOR) (Schajer 2001; Lam et al. 2005; Roblot et al. 2010; Briggert et al. 2016; Hu et al. 2018).

These currently used 3D visualization systems for the assessment of the distribution of defects in sawn wood are based on the implemented systems of control by an interactive data model with four types of parameters, i.e., width, length, defects, and the extent to which the defects are present. The development of such systems is based on the comparison of total values of the identified defects with their sizes, shapes, and 
lengthwise or crosswise positions in the sawn wood (Klinea et al. 2001; Lin et al. 2011; Hashim et al. 2015; Urbonas et al. 2019).

The basic hypothesis adopted in the present study was to confirm the theory that the number of knots and their incidence on a surface affect the evaluation of butt-end logs of sawn wood with respect to its mechanical parameters. Modulus of elasticity was adopted as an indicator for describing the technical parameters of the sawn wood. The tests were intended to provide information on the quality of 120-year-old Polish pine wood and on determination of its usefulness in the woodworking and construction industries. These evaluations were conducted to estimate the optimum mechanical and visual grading methods, applied to coniferous sawn wood.

\section{EXPERIMENTAL}

The authors verified the usefulness of sawn pine wood (Pinus sylvestris L.). Test samples of the size $3500 \mathrm{~mm} \times 138 \mathrm{~mm} \times 40 \mathrm{~mm}$ (length $\times$ width $\times$ thickness) logs were purchased from Southern Poland forest division Olesno (Southern Poland, Forest stand of 120 years). The lumber for the research came from the central part of the butt logs. One piece each of sawn wood without core, obtained from 27 model trees, was examined. In this study, the parapet part represents the technical characteristics of wood (Jelonek et al. 2012; Wąsik et al. 2016). The anatomy of the sawn wood was assessed with respect to the presence of knots, which in turn referred to its mechanical and physical properties, i.e., modulus of elasticity and apparent density with $12 \%$ moisture as shown in Table 1 (EN 408 2010+A1 2012; EN 384 2016). The MOE was determined according to EN 408:2010+A1 (2012) for the bending test. The test material was assessed by measuring the knots present in its various zones starting from the butt-end, followed by manual digitalization and mapping with regard to the frequency and incidence (share in the measured surface) of the defect (Fig. 1).

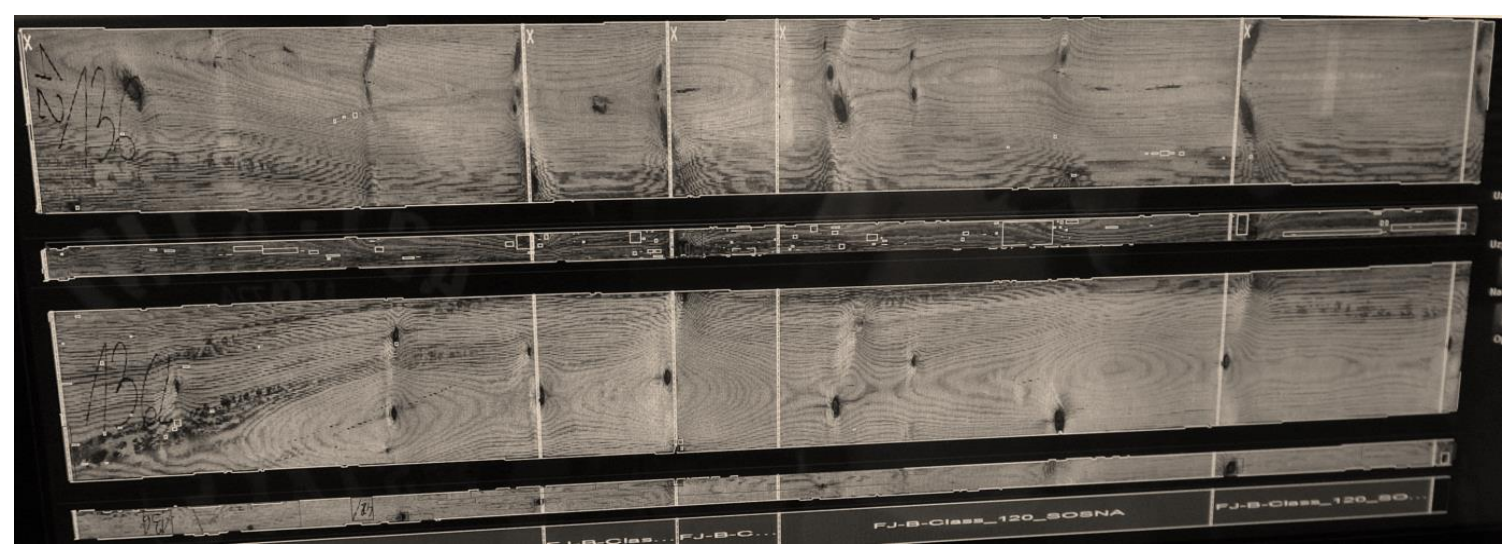

Fig. 1. Projection of a digital image of a sawn wood sample

For visual evaluation of knots, the results of measurements on the LUXSCAN CombiScan Evo C 20 industrial scanner (Racot Sawmill, Racot, Poland) were used. The image of knot distribution was used to determine the frequency of occurrence on the width and length of the lumber. The lumber was evaluated in the direction from the buttend. 
This study was based on the assessment of generated sawn wood segments, comprising a $10 \mathrm{~mm} \times 100 \mathrm{~mm}$ knot zone. The following parameters were evaluated:

- Lengthwise frequency of knots in the sawn wood (Fig. 1) as the number of lengthwise clusters of defects,

- Crosswise incidence of knots, referred to the number of defects in the measured sections (Fig. 2),

- Soundness of knots indicating the extent of the wood decay.

Table 1. Properties of Test Material

\begin{tabular}{|c|c|c|c|c|c|c|c|c|}
\hline No. & $\begin{array}{c}\mathrm{MOE} \\
\left(\mathrm{kN} / \mathrm{mm}^{2}\right)\end{array}$ & $\begin{array}{c}\rho \\
\left(\mathrm{kg} / \mathrm{m}^{3}\right)\end{array}$ & No. & $\begin{array}{c}\mathrm{MOE} \\
\left(\mathrm{kN} / \mathrm{mm}^{2}\right)\end{array}$ & $\begin{array}{c}\rho \\
\left(\mathrm{kg} / \mathrm{m}^{3}\right)\end{array}$ & No. & $\begin{array}{c}\mathrm{MOE} \\
\left(\mathrm{kN} / \mathrm{mm}^{2}\right)\end{array}$ & $\begin{array}{c}\rho \\
\left(\mathrm{kg} / \mathrm{m}^{3}\right)\end{array}$ \\
\hline 1 & 10,00 & 531 & 10 & 12,66 & 552 & 19 & 10,54 & 645 \\
\hline 2 & 13,27 & 588 & 11 & 11,43 & 542 & 20 & 16,15 & 685 \\
\hline 3 & 10,47 & 631 & 12 & 10,31 & 526 & 21 & 9,77 & 561 \\
\hline 4 & 15,19 & 658 & 13 & 7,25 & 481 & 22 & 9,56 & 598 \\
\hline 5 & 10,28 & 618 & 14 & 15,52 & 615 & 23 & 11,22 & 616 \\
\hline 6 & 11,31 & 497 & 15 & 12,02 & 531 & 24 & 9,59 & 507 \\
\hline 7 & 13,16 & 583 & 16 & 11,16 & 536 & 25 & 14,53 & 655 \\
\hline 8 & 13,11 & 546 & 17 & 13,80 & 686 & 26 & 9,02 & 552 \\
\hline 9 & 7,87 & 469 & 18 & 12,48 & 644 & 27 & 10,79 & 586 \\
\hline
\end{tabular}

Most practices in the automatic grading of sawn wood involve detection of defects. In addition to the analysis of their occurrence, this study assessed the wood soundness by detecting discolored knot surfaces (Fig. 2). The knots in a critical condition were graded as 1 to 4 on the defect scale: 1 for a sound light knot, 2 for a sound dark knot, 3 for a partly decayed dark knot (minimum 1/3 of the knot surface is decayed), and 4 for a decayed knot (more than 1/3 of the knot surface is decayed). To specify the share of the defect along the sawn wood test sample, the crosswise incidence of knots was calculated for $1 / 14$ of the cross-section of the pine wood sample (at $10 \mathrm{~mm}$ intervals). The authors delineated zones taking into account division into the examined areas of the tested sawn wood longitudinally and crosswise.

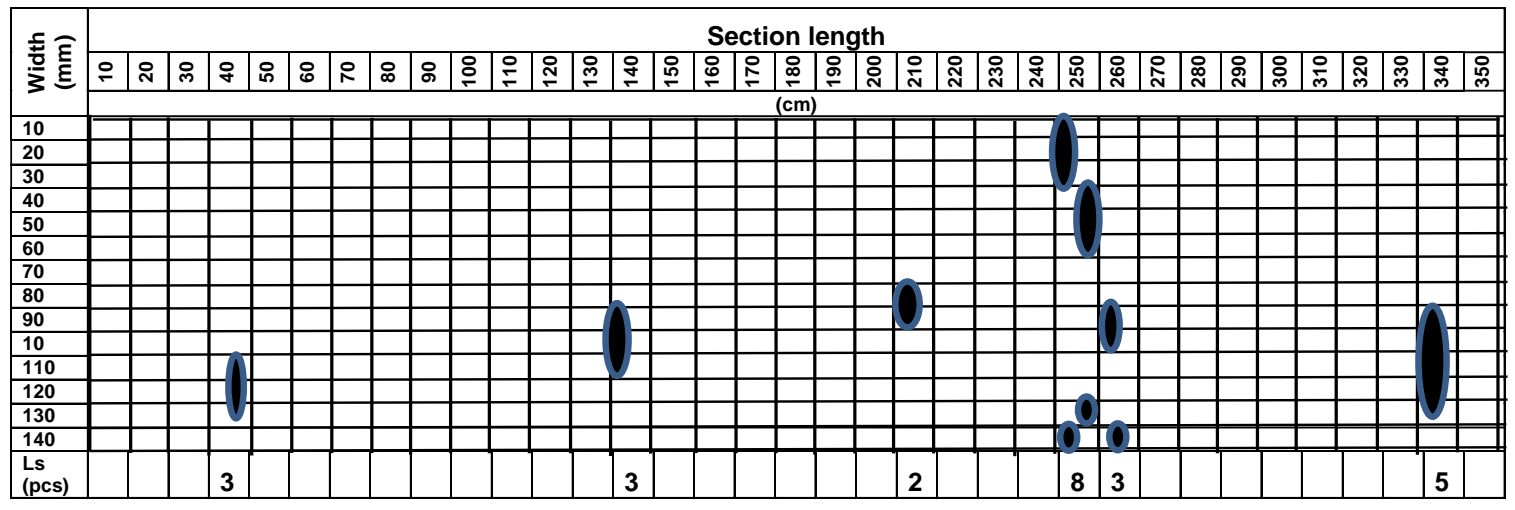

Fig. 2. Determination of knottiness frequency and the principles of separation of knot incidence zones; Ls (pcs) denotes the number of sections with knots (pcs)

The frequency of knots was calculated as the product of the number of sections with defects on the lumber length and the number of pieces of lumber with defects divided by the number of all section tested boards. The incidence of knots was calculated as the product of the number of sections with knots on the width and length of the lumber 
and the number of pieces of lumber with defects, divided by the number of all sections of the tested boards.

\section{RESULTS}

The frequency of knots along the sawn pine wood test sample (Table 2) was measured. The results indicated that there was no correlation between the knot distribution and the length of the sawn wood samples. Furthermore, a considerably increased incidence of knots, with peaks occurring at approximately $150 \mathrm{~cm}$ intervals was observed.

To specify the share of the defect along the sawn wood test sample, the crosswise incidence of knots and the results are shown in Table 2. The distribution of the defect incidence indicates that the number of knots in the sawn wood sample was slightly increasing starting from the butt-end toward the top. Moreover, the incidence of knots was found to increase at intervals ranging from $40 \mathrm{~cm}$ to $70 \mathrm{~cm}$.

Table 2. Lengthwise Frequency and Incidence of Knots in the Butt-end Sawn Pine Wood

\begin{tabular}{|c|c|c|c|c|c|}
\hline $\begin{array}{c}\text { Distance } \\
(\mathrm{cm})\end{array}$ & $\begin{array}{c}\text { Frequency of } \\
\text { Knots (\%) }\end{array}$ & $\begin{array}{c}\text { Incidence of } \\
\text { Knots (\%) }\end{array}$ & $\begin{array}{c}\text { Distance Along } \\
\text { the Butt-end } \\
(\mathrm{cm})\end{array}$ & $\begin{array}{c}\text { Frequency of } \\
\text { Knots (\%) }\end{array}$ & $\begin{array}{c}\text { Incidence of } \\
\text { Knots (\%) }\end{array}$ \\
\hline 10 & 0.8 & 0.8 & 190 & 6.6 & 6.5 \\
\hline 20 & 1.9 & 1.5 & 200 & 5.2 & 4.4 \\
\hline 30 & 5.5 & 5.8 & 210 & 0.5 & 0.3 \\
\hline 40 & 3.8 & 4.0 & 220 & 3.0 & 2.3 \\
\hline 50 & 2.5 & 1.9 & 230 & 3.3 & 3.2 \\
\hline 60 & 1.4 & 1.4 & 240 & 3.6 & 2.7 \\
\hline 70 & 1.4 & 1.8 & 250 & 3.0 & 2.0 \\
\hline 80 & 3.0 & 3.2 & 260 & 3.8 & 5.1 \\
\hline 90 & 2.2 & 1.9 & 270 & 3.0 & 2.9 \\
\hline 100 & 3.6 & 4.0 & 280 & 1.9 & 1.4 \\
\hline 110 & 1.9 & 2.6 & 290 & 2.2 & 3.0 \\
\hline 120 & 2.2 & 2.6 & 300 & 3.8 & 4.3 \\
\hline 130 & 3.6 & 3.3 & 310 & 1.4 & 1.6 \\
\hline 140 & 1.9 & 2.3 & 320 & 3.6 & 2.3 \\
\hline 150 & 2.5 & 2.6 & 330 & 4.9 & 5.4 \\
\hline 160 & 1.9 & 1.9 & 340 & 3.6 & 3.9 \\
\hline 170 & 2.5 & 2.7 & 350 & 1.6 & 1.9 \\
\hline 180 & 2.7 & 2.5 & & & \\
\hline
\end{tabular}

The relationship between the frequency of knots in the sawn wood and its strength indicators is illustrated in Fig. 3. The frequency of knot zones in lumber indicates its low correlation with the strength of the tested material. Average values show the intensity of defects at the level from $5 \%$ to $9 \%$ of the frequency. In Fig. 3, averaged percentages 
show a somewhat dissipated distribution of the frequency of the defect along the test sample. Moreover, the trend curve indicates that the MOE tends to decrease with increasing knot incidence.

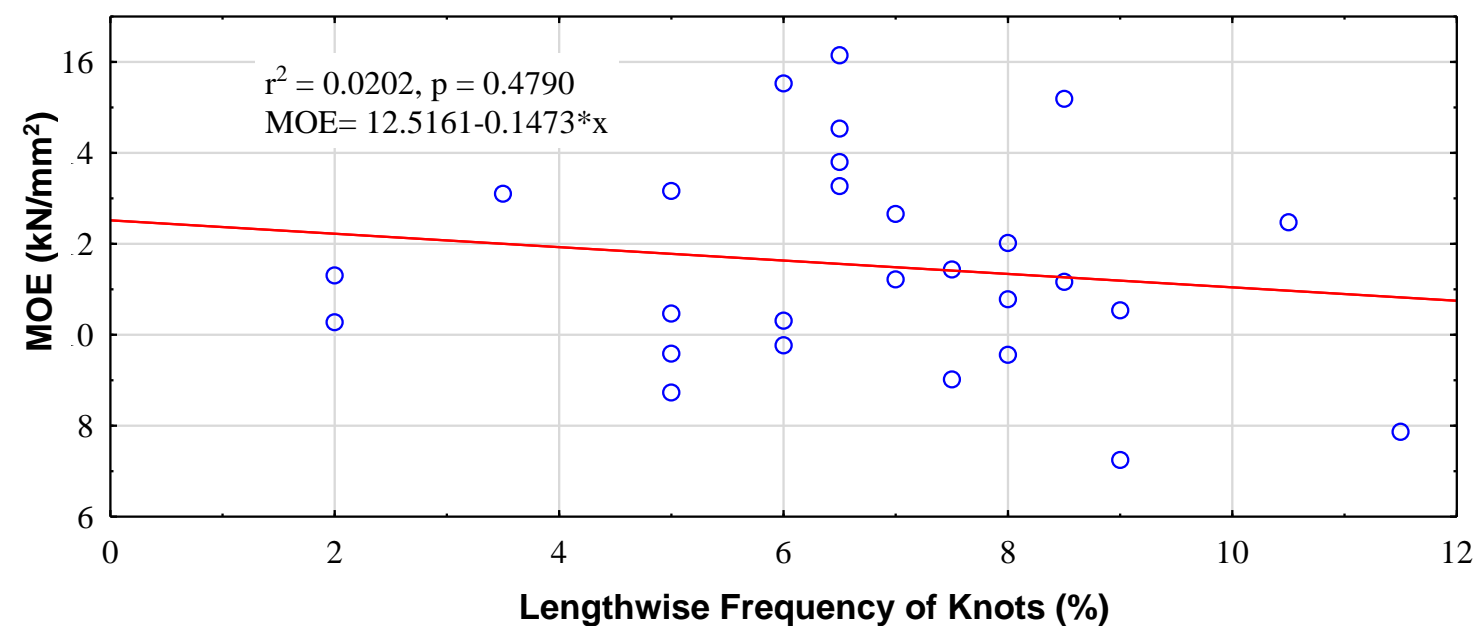

Fig. 3. Relationship between MOE and lengthwise frequency of knots

The impact of the incidence of knots in the respective sections of the test sample on the MOE of sawn wood is illustrated in Fig. 4. The values of MOE tend to decrease with increasing incidence of knots on the sawn wood surface. This confirms the results of previous studies (Klinea et al. 2001; Krzosek 2002; Wright et al. 2019) concerning the impact of knots in sawn wood on its strength, as illustrated by its MOE. Lack of continuity in the structure of the wood (knots) and the distortion of grain reduce the effective cross-section of sawn timber.

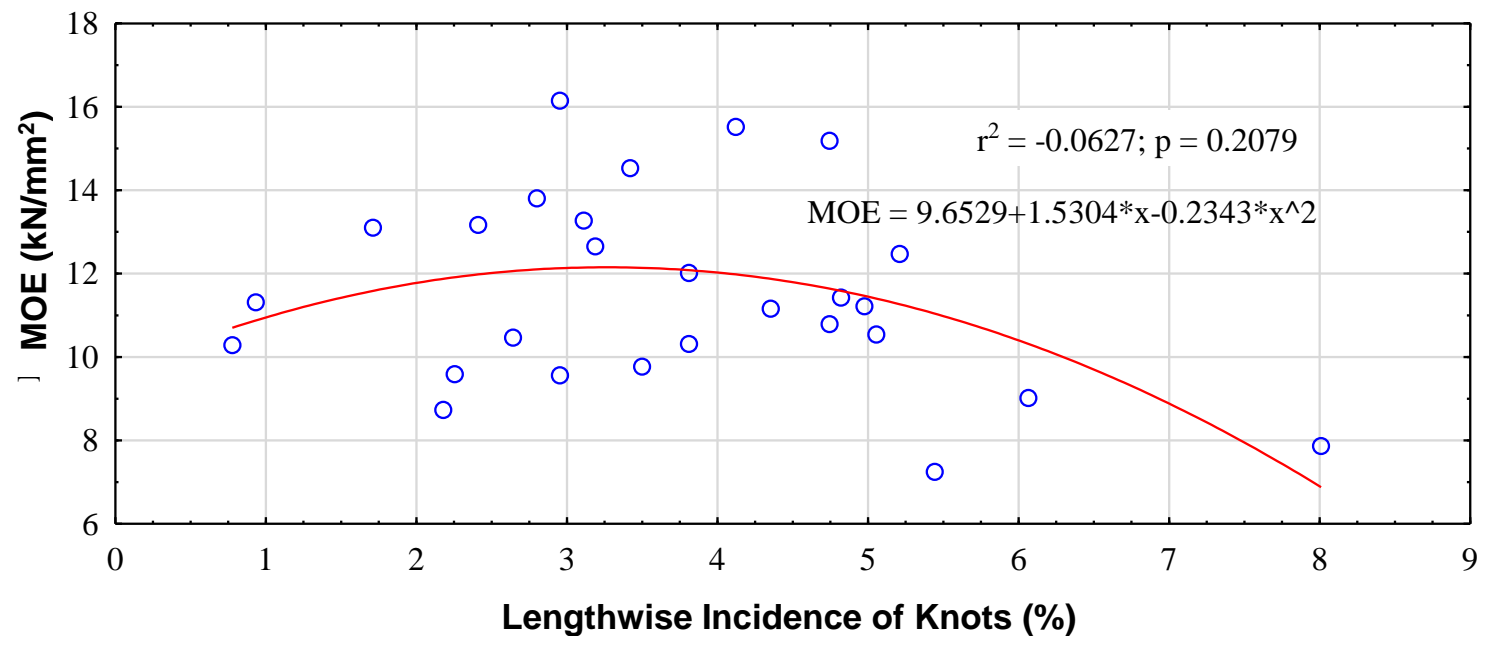

Fig. 4. Relationship between MOE and lengthwise incidence of knots in sawn wood 
The impact of the defect of interest (knots) on the selected timber density of sawn wood was assessed. The assessed lumber density was the average value for the whole tested board. Even though the distribution of knots was highly variable in the test samples, their impact on the density of sawn wood was not observed (Fig. 5). No correlation between these parameters was confirmed.

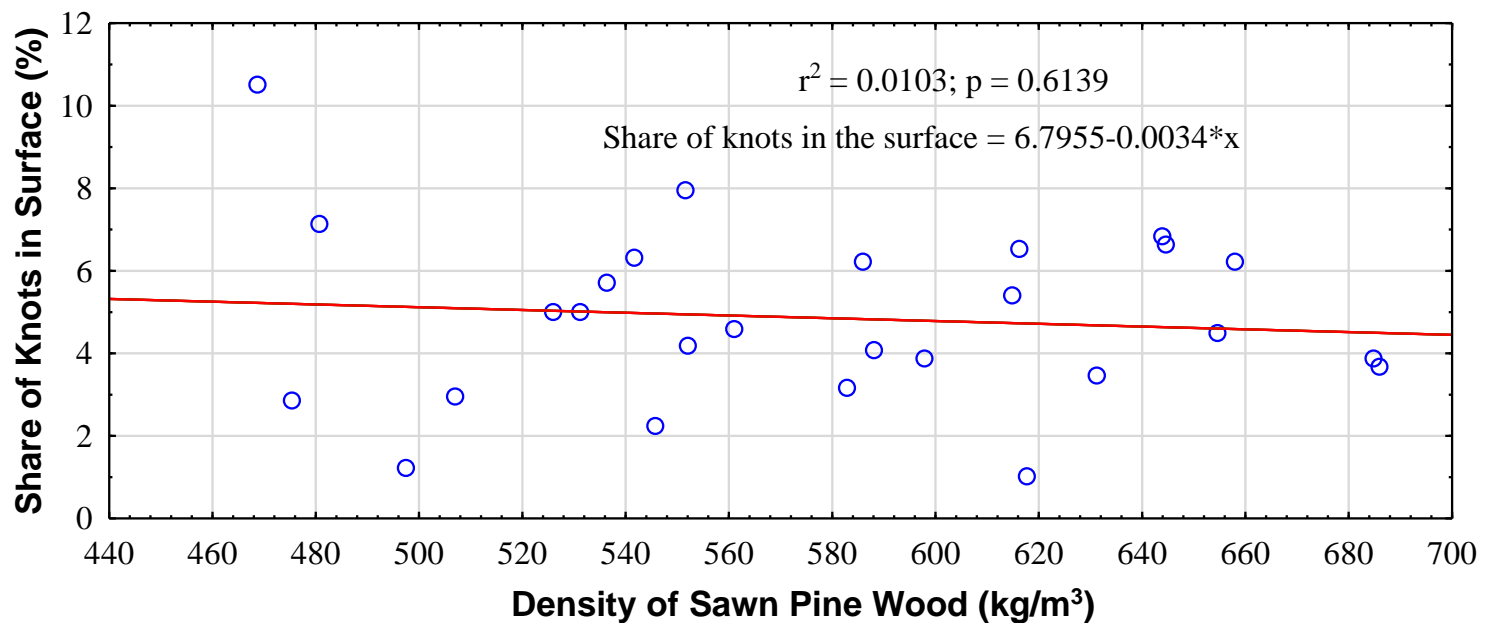

Fig. 5. Relationship between density and incidence of knots in sawn wood

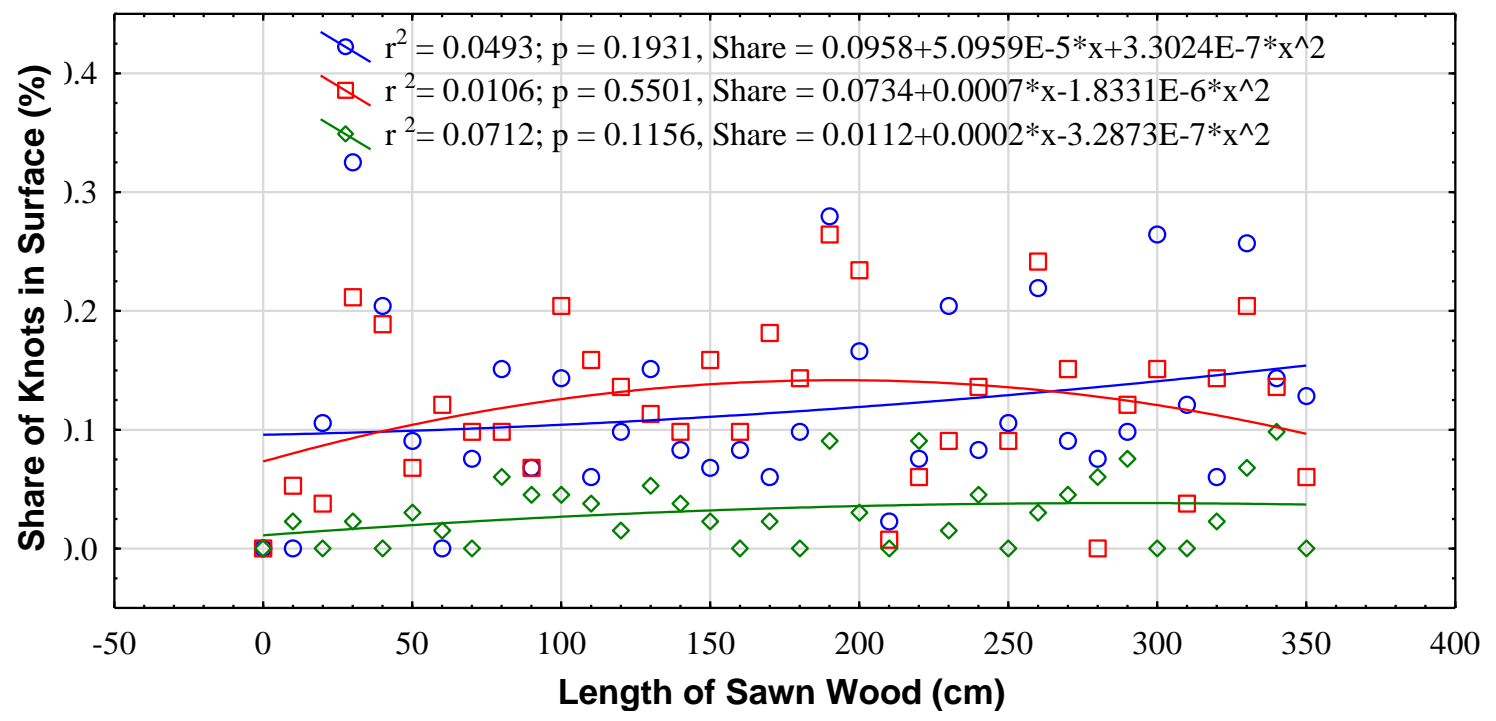

Fig. 6. Lengthwise distribution of sound knots in the sawn wood: 1- for a sound light knot; 2- for a sound dark knot; and 3- for a partly decayed dark knot

Verification of the distribution of knots in the sawn pine wood enables an assessment of the soundness of the defect of interest (Fig. 6). Using the adopted wood grading method, no decayed knots were found in the tested population. The results of grading indicated that the percentage of light and dark sound knots was $4 \%$ each. Moreover, the distribution of light knots was growing along the sawn pine wood starting from the butt- end toward the top of the test sample.

An assessment of the increasing incidence of dark sound knots enables the observation that they are evenly distributed along the test sample. There is no correlation 
between their distribution and location along the test sample. The share of partly decayed knots along the test sample increased linearly toward the top and its total percentage in the surface of the test sample exceeded $1 \%$.

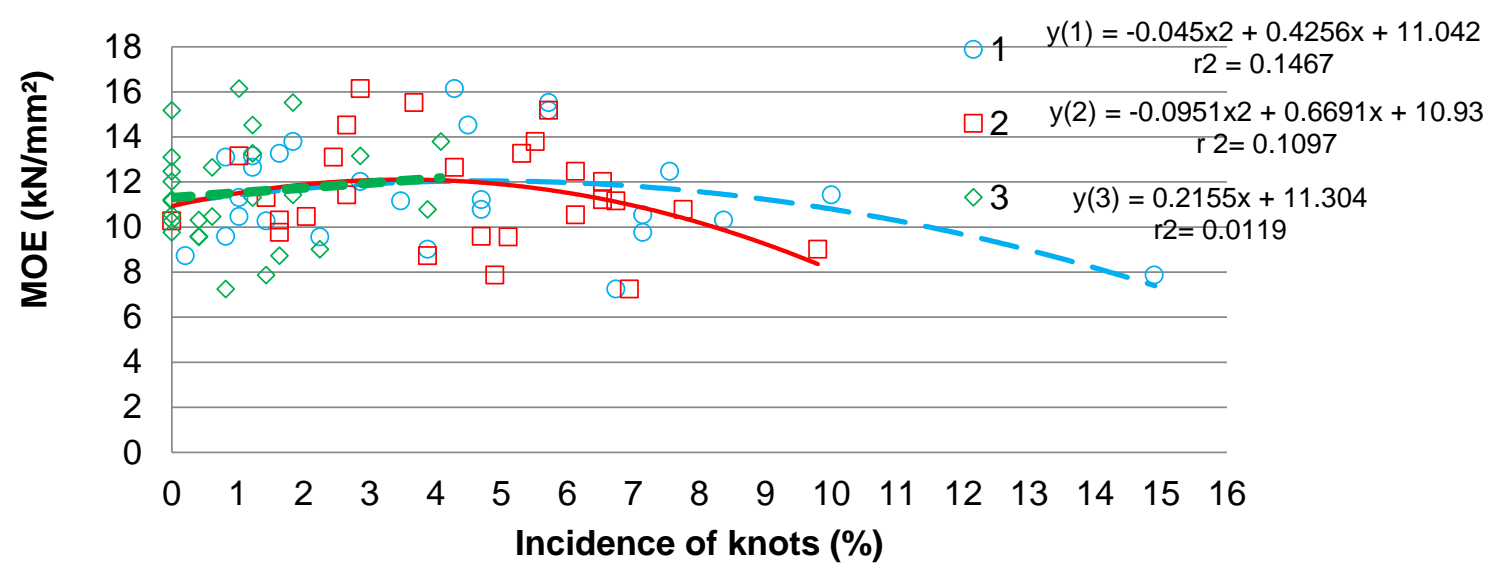

Fig. 7. Relationship between soundness of knots and MOE for sawn pine wood: 1 - for a sound light knot; 2- for a sound dark knot; and 3- for a partly decayed dark knot

The impact of knot soundness in the sawn pine wood on its MOE, as determined in the bending test (Fig. 7), indicated a noticeable role of both the dark and light sound knots. The distribution of decayed knots was not found to have any impact. The studies on the relationship between knottiness and MOE of Polish pine wood confirmed that knottiness is an important factor in such analyses.

\section{DISCUSSION}

The analyzed data on the relationships between the durability properties and technological properties of Polish pine wood indicated the same tendency as that presented for European raw materials. Modulus of elasticity, the essential indicator of the technological value of wood, determines its usefulness not only in wood industry but also in the construction business. Being a directly correlated indicator of strength, it is also directly connected with the presence of structural defects of wood (Schajer 2001; Lam et al. 2005; Fabisiak et al. 2009; Roblot et al. 2010; Hu et al. 2018). In regards to Polish lumber from the thick end of a log, the surface of knots in the cross-section (knot area ratio) of the test sample has a noticeable impact on the value of MOE. The impact of the length frequency of knots is much less pronounced. This study confirmed that the share of sound knots was indisputably the chief factor influencing the value of MOE. The share of decayed knots was a low percentage (below 1\%) on the wood surface. The impact of broken knots on the MOE has not been observed. This was the result of the origin of core sawn timber from the first model tree logs. The impact of a few broken knots on the MOE was difficult to estimate. The results of the other studies showed that a higher share of decayed knots may considerably deteriorate the mechanical properties of sawn wood (Lin et al. 2011; Olsson and Oscarsson 2017). The tests carried out did not confirm the correlation between the density and the proportion of knots. This study confirmed no correlation between the share of knots and the density of sawn wood. This may be influenced by the origin of the sawn timber from the core part of the butt logs with a high 
proportion of juvenile wood. In contrast, general studies on knots indicate that the correlation does exist and is connected with structural changes within and around the knots (Oh et al. 2009; Mäkinen et al. 2020). The present study is an introduction to broader studies on the verification of the properties of Polish pine wood. The presented testing enabled the authors to direct algorithm modeling and defect image processing with a view to obtaining more precise quality grades of wood. The essential steps of the sawn wood tests were to separate the wood regions (sections) comprising the defects of interest and evidence of a less or more pronounced damage of the knot tissue. The tests enabled an assessment of the incidence of knots for average types of core part of the butt logs sawn wood and the effect of such defects on technological output (share of sawn wood characterized by specific strength).

The growing precision and performance of available coarse-processing equipment and software can contribute to improvement of the productivity of lumber in decisionmaking processes when processing the material. The knot measuring principles are based on the solutions offered by the available scanning systems, which enable the detection of internal defects with high accuracy. Algorithms used in woodworking software provide optimal solutions for identifying the location and type of defects

\section{CONCLUSIONS}

1. The distribution of knots in pine wood was characterized by repeated incidence every $40 \mathrm{~cm}$ to $70 \mathrm{~cm}$. The incidence of knots in the test material was approximately $4 \%$ both for the light and dark sound knots. The share of partly decayed knots was only $1 \%$ of the surface of the sawn wood tested.

2. The correlation between the increase in MOE and incidence of sound knots was positive.

3. The frequency of decayed knots changed much less strongly in the central zone of the $\log$. The highest incidence of the partly decayed knots was observed only in the initial section of the butt-end logs.

4. Sound dark knots were uniformly distributed along the whole test material.

\section{Conflicts of Interest}

The authors declare no conflicts of interest.

\section{Author Contributions}

Wieruszewski Marek and Trociński Adrian designed the research constellation. Authors Łabęda Karol and Kawalerczyk Jakub led the data collection procedure. Mirski Radosław and Wieruszewski Marek conducted the analysis and wrote the manuscript together. All authors have read and agreed to the published version of the manuscript.

\section{ACKNOWLEDGMENTS}

This study was financed by the Polish National Centre for Research and Development within the framework of grant BIOSTRATEG3/344303/14/NCBR/2018. 
The publication was co-financed within the framework of the Ministry of Science and Higher Education program "Regional Initiative Excellence" in years 2019 to 2022, Project No. 005/RID/2018/19.

\section{REFERENCES CITED}

Almecija, B., Choffel, D., Daquitaine, R., Bombardier, V., and Charpentier, P. (2013). "Economical interest of a X-rays vision system in a planning mill production chain," Journal of Physics: Conference Series 416(1), Article ID 012025. DOI: 10.1088/1742-6596/416/1/012025

Baltrušaitis, A. (2000). "Investigation of influence of knots on short - and long - term strength of glulam beams," in: World Conference on Timber Engineering, British Columbia, BC, Canada.

Belley, D., Duchesne, I., Vallerand, S., Barrette, J., and Beaudoin, M. (2019). “Computed tomography (CT) scanning of internal log attributes prior to sawing increases lumber value in white spruce (Picea glauca) and jack pine (Pinus banksiana)," Canadian Journal of Forest Research 49(12), 1516-1524. DOI: 10.1139/cjfr-2018-0409

Brännströma, M., Manninenb, J., and Oja, J. (2008). "Predicting the strength of sawn wood by tracheid laser scattering," BioResources 3(2), 437-451.

Briggert, A., Olsson, A., and Oscarsson, J. (2016). "Three-dimensional modelling of knots and pith location in Norway spruce boards using tracheid-effect scanning," European Journal of Wood and Wood Products 74(5), 725-739. DOI:

10.1007/s00107-016-1049-7

Burawska, I., Jachowicz, P., Zbieć, M., and Grześkiewicz, M. (2014). “Local reinforcement of naturally defected structural lumber," Annals of Warsaw University of Life Sciences - SGGW Forestry and Wood Technology 87(3), 25-34.

Burawska, I., Zbieć, M., Kaliciński, J., and Beer, P. (2013). "Technical simulation of knots in structural wood," Annals of Warsaw University of Life Sciences - SGGW Forestry and Wood Technology 82(2), 105-112.

Chmielowski, J., Kozakiewicz, P., and Buraczyk, W. (2018). "Variability of annual rings and density of Scots pine (Pinus sylvestris L.) wood of Bolewice origin from the provenance surface in Rogów," Annals of Warsaw University of Life Sciences SGGW Forestry and Wood Technology 102(2), 11-15.

Dahlen, J., Montes, C., Eberhardt, T. L., and Auty, D. (2018). "Probability models that relate nondestructive test methods to lumber design values of plantation loblolly pine," Forestry 91(3), 295-306. DOI: 10.1093/forestry/cpy001

Duchateau, F., Longuetaud, F., Mothe, F., Ung, C., Auty, D., and Achim, A. (2013). "Modelling knot morphology as a function of external tree and branch attributes," Canadian Journal of Forest Research 43(3), 266-277. DOI: 10.1139/cjfr-2012-0365

Dzbeński, W. (1995). "Polish construction timber against European standards," in: IX Konferencja Naukowa Wydziału Technologii Drewna SGGW, Warszawa, Poland.

EN 384 (2016). "Structural timber- Determination of characteristic values of mechanical properties and density," European Committee for Standardization, Brussels, Belgium.

EN 408 2010+A1 (2012). "Timber structures. Structural timber and glued laminated timber. Determination of some physical and mechanical properties," European Committee for Standardization, Brussels, Belgium. 
Fabisiak, E., Cunderlik I., and Moliński, W. (2009). "Variation in the microfibryl angle in tangent walls of tracheids in individual Anna rings of intermediate pine trees (Pinus sylvestris L.)," Annals of Warsaw University of Life Sciences - SGGW Forestry and Wood Technology 68(2), 231-239.

Flodin, J., Oja, J., and Grönlund, A. (2008). "Fingerprint traceability of sawn products using industrial measurement systems for X-ray log scanning and sawn timber surface scanning," Forest Products Journal 58(11), 100-105.

Hashim, U. R., Hashim, S. M., and Muda, A. (2015). "Automated vision inspection of timber surface defect: A review," Jurnal Teknologi 77(20), 127-135. DOI: 10.11113/jt.v77.6562

Hu, M., Briggert, A., Olsson, A., Johansson, M., Oscarsson, J., and Säll, H. (2018). "Growth layer and fibre orientation around knots in Norway spruce: A laboratory investigation," Wood Science and Technology 52(1), 7-27. DOI: 10.1007/s00226017-0952-3

Jelonek, T., Pazdrowski, W., Tomczak, A., and Grzywiński, W. (2012). "Biomechanical stability of pines growing on former farmland in northern Poland," Wood Research 57(1), 31-44.

Johansson, E., Johansson, D., Skog, J., and Fredriksson, M. (2013). “Automated knot detection for high speed computed tomography on Pinus sylvestris L. and Picea abies (L.) Karst. using ellipse fitting in concentric surfaces," Computers and Electronics in Agriculture 96, 238-245. DOI: 10.1016/j.compag.2013.06.003

Klinea, D. E., Aramanb, P., and Surakc, C. (2001). "Evaluation of an automated hardwood lumber grading system," in: Proceedings of Scandinaw Technology International Conference, Seattle, WA, USA, pp. 141-151.

Krzosek, S. (2002). "Wytrzymałościowe sortowanie tarcicy w procesie produkcji elementów konstrukcyjnych z drewna klejonego warstwowo [High-strength sorting of sawn timber in the process of production of structural elements made of glued laminated timber]," Przemyst Drzewny 3, 32-33.

Krzosek, S. (2009). "Wytrzymałościowe sortowanie polskiej, sosnowej tarcicy konstrukcyjnej różnymi metodami [High-strength sorting of Polish structural pine lumber using different methods]," in: Wydawnictwo $S G G W$, Warsaw, Poland.

Lam, F., Barrett, J. D., and Nakajima, S. (2005). "Influence of knot area ratio on the bending strength of Canadian Douglas fir timber used in Japanese post and beam housing," Journal of Wood Science 51(1), 18-25. DOI: 10.1007/s10086-003-0619-6

Lin, W., Wang, J., and Sharma, B. (2011). "Development of an optimal threedimensional visualization system for rough lumber edging and trimming in central Appalachia," Forest Products Journal 61(5), 401-410. DOI: 10.13073/0015-747361.5.401

Lukacevic, M., Kandle, R. G., Hu, M., Olsson, A., and Füssl, J. A. (2019). “3D model for knots and related fiber deviations in sawn timber for prediction of mechanical properties of boards," Materials \& Design 166, Article ID 107617. DOI: 10.1016/j.matdes.2019.107617

Mäkinen, H., Korpunen, H., Raatevaara, A., Heikkinen, J., Alatalo, J., and Uusitalo, J. (2020). "Predicting knottiness of Scots pine stems for quality bucking," European Journal of Wood and Wood Products 78, 143-150. DOI:10.1007/s00107-019-01476-X

Oh, J., Shim, K., Kim, K., and Lee, J. (2009). "Quantification of knots in dimension lumber using a single-pass X-ray radiation,” Journal of Wood Science 55, 264-272. DOI: $10.1007 / \mathrm{s} 10086-009-1031-7$ 
Olsson, A., and Oscarsson, J. (2017). "Strength grading on the basis of high resolution laser scanning and dynamic excitation: a full scale investigation of performance," European Journal of Wood and Wood Products 75, 17-31. DOI: 10.1007/s00107016-1102-6

Roblot, G., Bléron, L., Mériaudeau, F., and Marchal, R. (2010). “Automatic computation of the knot area ratio for machine strength grading of Douglas-fir and Spruce timber," European Journal of Environmental Civil Engineering 14(10), 1317-1332. DOI: 10.1080/19648189.2010.9693296

Roszyk, E. (2016). "Mechanical parameters of Scots pine wood (Pinus sylvestris L.) upon tensile stress along the grains in relation to its moisture content and ultrastructure," Wydawnictwo UPP, Rozprawy Naukowe 485.

Rummukainen, H., Makkonen, M., and Uustitalo, J. (2018). "Economic value of optical and X-ray CT scanning in bucking of Scots pine," Wood Material Science \& Engineering (Online). DOI: 10.1080/17480272.2019.1672787

Schajer, G. S. (2001). "Lumber strength grading using X-ray scanning," Forest Products Journal 51(1), 43-52. DOI: 10.1007/s00107-019-01441-8

Urbonas, A., Raudonis, V., Maskeliunas, R., and Damasevicius, R. (2019). “Automated identification of wood veneer surface defects using faster region-based convolutional neural network with data augmentation and transfer learning," Applied Sciences 9(22), article no. 4898. DOI: 10.3390/app9224898

Wąsik, R., Michalec, K., and Mudryk, K. (2016). "Variability in static bending strength of the "Tabórz" Scots pine wood (Pinus sylvestris L.)," Drewno 59(196), 153-162. DOI: 10.12841/wood.1644-3985.132.11

Wright, S., Dahlen, J., Montes, C., and Eberhardt, T. L. (2019). “Quantifying knots by image analysis and modeling their effects on the mechanical properties of loblolly pine lumber," European Journal of Wood and Wood Products 77, 903-917. DOI: 10.1007/s00107-019-01441-8

Article submitted: September 2, 2020; Peer review completed: October 31, 2020; Revised version received and accepted: December 12, 2020; Published: January 22, 2021.

DOI: 10.15376/biores.16.1.1842-1853 